\title{
Phyto Contact Dermatitis Caused by Ranunculus Damascenus: A Case Report
}

\author{
Ranunculus Damascenus'un Neden Olduğu Fito Kontakt Dermatit: Bir Olgu Sunumu
}

\author{
Ömer Elmas', Okan Kızılyel', Mahmut Sami Metin², Handan Bilen', Mustafa Atasoy' \\ ${ }^{1}$ Faculty of Medicine, Dermatology Department, Atatürk University, Erzurum, Turkey; ${ }^{2}$ Afşin State Hospital, Dermatology Clinic, \\ Kahramanmaras, Turkey
}

\begin{abstract}
Phyto contact dermatitis is a skin reaction caused by plants. Allergic contact dermatitis and irritant contact dermatitis are the most common forms of the entity. Ranunculaceae is a family of plants that has irritant and toxic potential due to content of ranunculin. We have reported a 57 year-old woman with a phyto contact dermatitis following the application of Ranunculus Damascenus on her knees to relieve the joint pain. The patient was treated completely with wound dressing, topical antibiotics, systemic antihistamines and a short course of systemic methylprednisolone. According to our knowledge this is the second case report of phyto contact dermatitis in literature associated with Ranunculus Damascenus.
\end{abstract}

Key words: contact dermatitis; irritant dermatitis; ranunculus

\section{ÖZET}

Fito kontakt dermatit bitkilerden kaynaklanan bir deri reaksiyonudur. Alerjik kontakt dermatit ve irritan kontakt dermatit bu antitenin en sık nedenleridir. Ranunculaceae, ranunculin içeriğinden dolayı irritan ve toksik potansiyele sahip bir bitki familyasıdır. Eklem ağrısı için dizlerine Ranunculus Damascenus uygulayan ve sonrasında fito kontakt dermatit gelișen 57 yașında kadın hastayı sunduk. Hasta yara pansumanı, topikal antibiyotikler, sistemik antihistamikler ve kısa süreli sistemik metilprednizolone ile tamamen tedavi edildi. Bildiğimiz kadarıla bu Ranunculus Damascenus'a bağlı gelișen literatürdeki ikinci olgu sunumudur.

Anahtar kelimeler: kontakt dermatit; irritan dermatit; ranunculus

Asistan Okan Kizllyel, Atatürk Üniversitesi Dermatoloji Kliniği 5. kat Erzurum Merkez, 25000 Erzurum, Türkiye,

Tel.05542304603 Email.erester.34@hotmail.com

Geliş Tarihi: 08.11.2014 • Kabul Tarihi: 09.03.2015

\section{Introduction}

Some plants contain numerous different chemical substances which can cause allergic responses. A large number of skin reactions caused by plants have been identified. These reactions are also called phyto contact dermatitis and can be classified as allergic contact dermatitis, irritant contact dermatitis, photo allergic contact dermatitis, photo toxic contact dermatitis and contact urticaria. The most common forms of phyto contact dermatitis are allergic contact dermatitis and irritant contact dermatitis ${ }^{1}$. Herein, we presented a case of irritant contact dermatitis developed after Ranunculus Damascenus application to relieve the joint pain.

\section{Case Report}

A 57 year-old woman living in the rural area of Erzurum was admitted to our clinic with a complaint of redness, pain, burning and blister formation on both knees. She had applied a plant with yellow flowers and green leaves on her knees for about 20 minutes to relieve joint pain (Figure 1).

The lesions aroused approximately 6 hour after the removal of the occlusive cloth three days ago. Dermatological examination revealed intact and ruptured bullous lesions on erythematous bases, extending from the upper part of both knees to the proximal part of the lower legs (Figure 2). Lesions were limited to contact area and mucous membranes were unaffected.

Cultures obtained from the lesion were negative. Complete blood count revealed a white cell count of $12800 / \mathrm{mm}^{3}$ (normal range: $4.3-10.8 \times 10^{3} / \mathrm{mm}^{3}$ ) and 


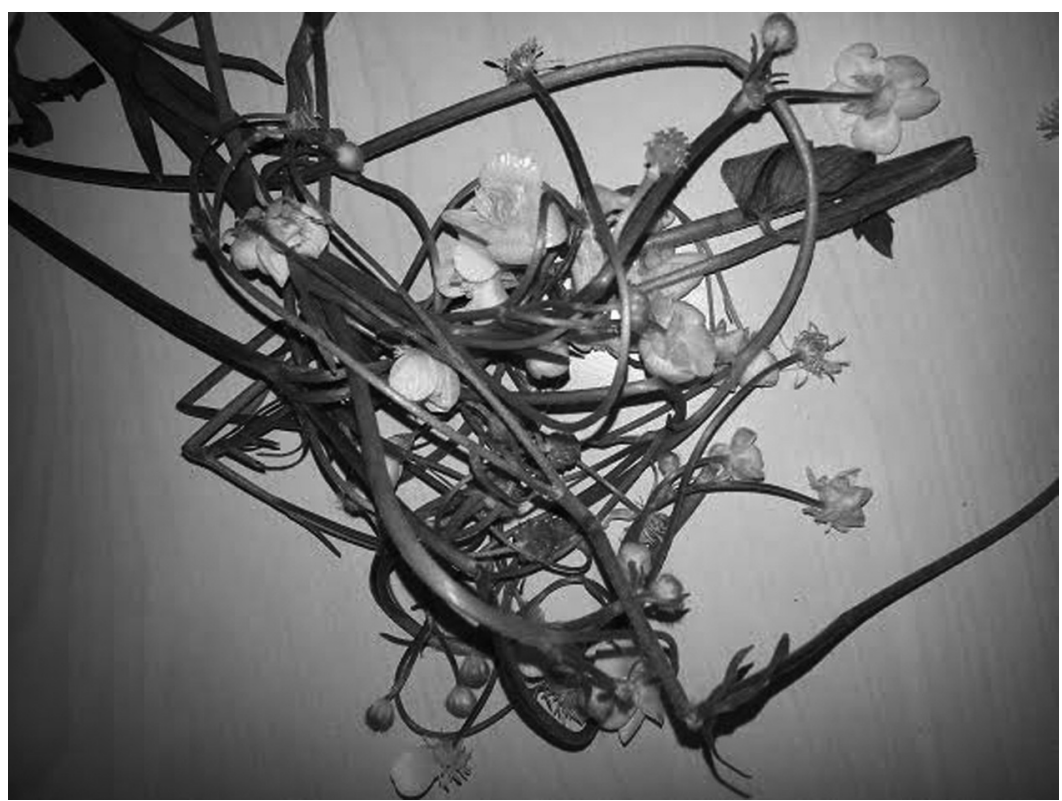

Figure 1. Ranunculus Damascenus.

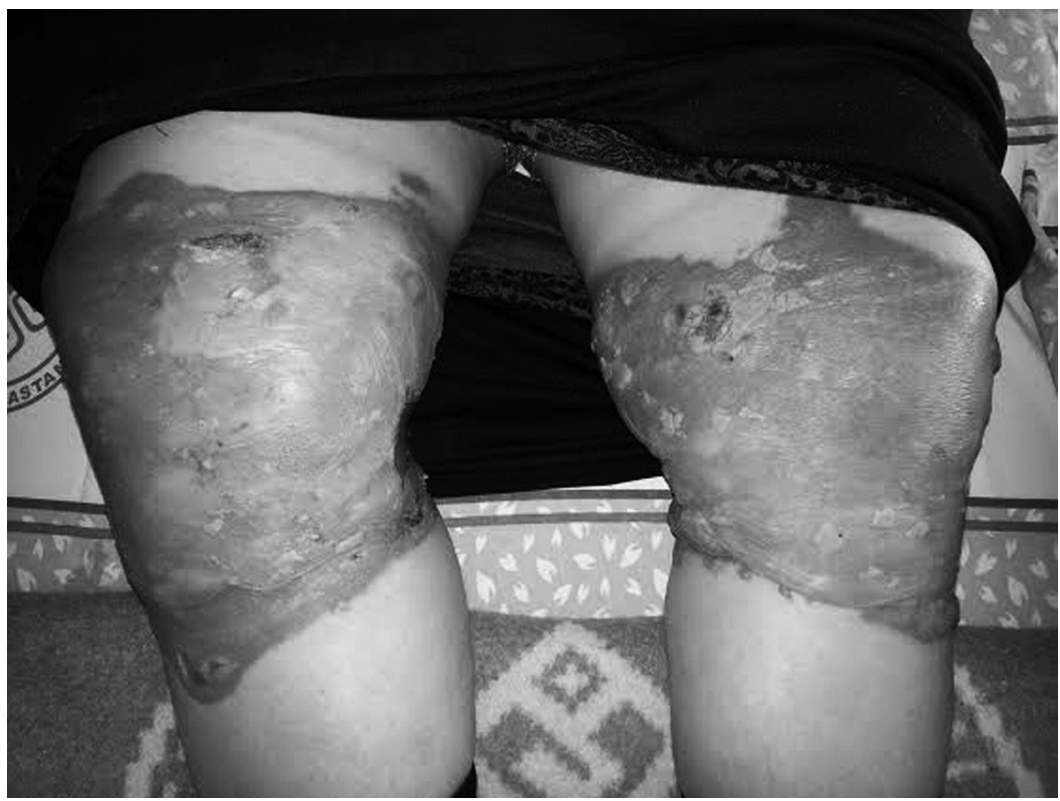

Figure 2. Intact and ruptured bullous lesions on erythematous base, extending from the upper part of both knees to the proximal part of the lower legs.

an erythrocyte sedimentation rate of $23 \mathrm{~mm} / \mathrm{hr}$. (normal range: 1-20 mm/hr.). Routine biochemical tests were within normal limits. There was not any history of medication and chronic diseases except degenerative osteoarthritis. The patient had used the plant for the first time.

The patient refused to have the patch test. The plant was identified as Ranunculus Damascenus by the help of Botanic Department. The patient was diagnosed with phyto contact dermatitis caused by Ranunculus Damascenus and treated with topical wet dressings, topical antibiotics, systemic antihistamines and tapering course of systemic methylprednisolone $(40 \mathrm{mg}$ taper by $5 \mathrm{mg}$ /day for 8 days). Her lesions began to recover in 2-3 days and healed completely within 17 days. 


\section{Discussion}

Ranunculaceae family includes about 1900 species and approximately 70 members of them are found in Turkey ${ }^{2,3}$. Some members of the Ranunculaceae are irritant and toxic due to their ranunculin content. Ceratocephalus, Myosurus, Helleborus, Clematis, Ranunculus and Anemone species also contain ranunculin ${ }^{4,5}$.

Ranunculus Damascenus derives from the Damascena region of Syria, and is also found in the middle and southern Anatolian region of Turkey. It flowers in April-May, Our case was admitted in May.

Ranunculin is a toxic glycoside and broken down to protoanemonin. Protoanemonin leads to dermoepidermal separation and formation of blisters ${ }^{6,7}$. It inhibits DNA polymerase and increases free oxygen radical levels, causing the toxicity and irritant features of ranunculin. Protoanemonin polymerizes rapidly to harmless crystal form called anemonin. Dried plants don't contain protoanemonin so they are not irritant ${ }^{8,9}$.

Ranunculaceae species are widely used as traditional treatments for many cases such as haemorrhoids, burns, lacerations, abrasions and herbal remedies for myalgia and arthralgia ${ }^{10-12}$. In Turkey, this herb is found in Mediterranean, Eastern Anatolian and South eastern Anatolian regions particularly ${ }^{4}$. The location of majority of cases presented from Turkey is from eastern Anatolia region. There are approximately 25 cases in the literature about phyto contact dermatitis caused by Ranunculaceae species. Akbulut et al. performed a review study with 25 cases diagnosed with phyto contact dermatitis due to the species of the Ranunculaceae family. In this review most of the cases were middle or advanced aged women and duration of contact to the plant varied from 25 minutes to 2 days. Our case was a 57 year-old woman as consistent with literature, however the duration of contact to the plant was about just $20 \mathrm{~min}$. Despite the short contact duration, clinical picture was severe. Akbulut's study revealed that the degree of damage was increased by duration of contact ${ }^{9}$.

The most common forms of phyto contact dermatitis are allergic contact dermatitis and irritant contact dermatitis. Our case is an irritant contact dermatitis because the lesions were limited to the exposure area and occurred after the first use of the plant.

Metin et al described the first case of phyto contact dermatitis associated with Ranunculus Damascenus ${ }^{8}$.
Our case is the second case in literature according to our investigation. Metin's case was a 45 year-old woman presented with open wounds on the abdomen, right knee and neck. She had applied the plant overnight and the lesions resolved completely in 12 days. In our case, complete healing was achieved at the $17^{\text {th }}$ day, although we had to use corticosteroids. Patient's advanced age and more severe toxicity of the plant might have prolonged the healing period.

\section{Conclusion}

Ranunculaceae phyto contact dermatitis is a rare clinical entity. Even though there are some beneficial effects of these plants, they may cause serious adverse skin reactions.

\section{References}

1. Ozkol HU, Calka O, Akdeniz N, Pinar SM. Phytodermatitis in eastern Turkey: a retrospective, observational study. Dermatitis 2014; 25:140-6.

2. Li R Z, Ji X J. The cytotoxicity and action mechanism of ranunculin in vitro. Yao Hsueh Hsueh Pao 1993: 28:326-31.

3. Calka O, Akdeniz N, Özkol HU, et al. Irritant contact dermatitis caused by Ranunculus kotschyi Boiss in 6 cases. Contact Dermatitis 2011; 64:174-6.

4. Uçmak D, Ayhan E, Akkurt MZ, et al. Presentation of three cases with phyto contact dermatitis caused by Ranunculus and Anthemis genera. J Dermatolog Treat 2014; 25:467-9.

5. Davis PH. Flora of Turkey and the East Aegean Islands. Edinburgh University Press 1965:172-4.

6. Metin A, Calka O, Akdeniz N, Behcet L. Phytodermatitis from Ceratocephalus falcatus. Contact Dermatitis 2005: 52:314-6.

7. Eskitascioglu T, Dogan F, Sahin G, et al: An extraordinary chemical burn injury cause: buttercup, a report of five cases. Burns 2008; 34:727-30.

8. Metin A, Calka O, Behçet L, Yildirim E, et al. Phytodermatitis from Ranunculus damascenus. Contact Dermatitis 2001; 44:183.

9. Akbulut S, Semur H, Kose O, et al. Phytocontact dermatitis due to Ranunculus arvensis mimicking burn injury: report of three cases and literature review. Int J Emerg Med 2011; 21:4-7.

10. Towsent C C. Flora of Iraq. Ministry of Agriculture and Agrarian Reform Public of Iraq. Baghdad, 1980:707.

11. Tanker N, Koyuncu M, Coskun M. Farmasötik botanik. Ankara Üniviversitesi Eczacllık Fakültesi yayınları no. 78, Ankara 1998: 222-9.

12. Turner N J. Counter-irritant and other medicinal uses of plants in Ranunculaceae by native peoples in British Columbia and neighbouring areas. J Ethnopharmacol 1984; 11:181-201. 